co-funded by the European Regional Development Fund, ERDF). VM is supported by funds of a Miguel Servet type I programme (CP16/00033) (ISCIII, cofunded by ERDF).

Disclosure of Interest: None declared

DOI: 10.1136/annrheumdis-2018-eular.5614

\section{SAT0171 REVERSIBLE DECREASES IN ABSOLUTE NEUTROPHIL COUNT (ANC) IN RHEUMATOID ARTHRITIS (RA) PATIENTS (PTS) ON SARILUMAB: COMPARISON OF DOSE DELAY AND DOSE DECREASE VS CONTINUED TREATMENT}

J. R. Curtis ${ }^{1}$, G. St John ${ }^{2}$, M. Panucci ${ }^{2}$, J. A. Maldonado-Cocco ${ }^{3} .{ }^{1}$ Division of Clinical Immunology and Rheumatology, University of Alabama at Birmingham, Birmingham, United States, ${ }^{2}$ Regeneron Pharmaceuticals, Inc, Tarrytown, United States, ${ }^{3}$ Universidad de Buenos Aires, Buenos Aires, Argentina

Background: In randomized studies (RCTs: MOBILITY, TARGET and MON$A R C H$ ), and open-label [OLE] EXTEND, for those patients who experienced decreases in ANC this typically occurred early after initiating sarilumab. For sarilumab patients with decreased ANC in the RCTs and the OLE, we assessed the outcomes associated with either continuing treatment, decreasing the sarilumab dose or delaying the dose.

Objectives: The effects of a dose decrease (200 to $150 \mathrm{mg}$ ), dose delay (>17 days), vs no change in treatment were evaluated in RA patients who experienced decreased ANC while on sarilumab 150 or $200 \mathrm{mg}$ q2w. Outcomes data from patients in MONARCH, MOBILITY and TARGET, and MOBILITY and TARGET patients entering EXTEND were analyzed to compare the three strategies. In MONARCH, patients received sarilumab $200 \mathrm{mg}$ q2w. In MOBILITY and TARGET, patients received sarilumab 150 or $200 \mathrm{mg}$ q2w. In EXTEND, patients were switched to, or initiated on, $200 \mathrm{mg}$ q2w.

Table 1 Outcomes following dose delay, dose decrease, or continued treatment with sarilumab among pts who experienced $\mathrm{ANC}<1000 / \mathrm{mm}^{3}$ at any time

\begin{tabular}{|c|c|c|c|c|c|}
\hline \multicolumn{6}{|c|}{$\begin{array}{l}\text { Table: Outcomes following dose delay, dose decrease, or continued treatment with sorilumab among pts who } \\
\text { experienced ANC } \angle 1000 / \mathrm{mm}^{3} \text { at any time }\end{array}$} \\
\hline & \multicolumn{2}{|c|}{ RCTs } & \multicolumn{3}{|c|}{$\begin{array}{c}\text { OLF } \\
\end{array}$} \\
\hline $\begin{array}{l}\text { Total treated (N) } \\
\end{array}$ & & \multirow{2}{*}{\multicolumn{3}{|c|}{$\frac{1535}{147(11)}$}} \\
\hline $\begin{array}{l}\text { ANC }<1000 / \mathrm{mm}^{3} \text { at any time } \\
(\mathrm{n},(\%))\end{array}$ & & & & & \\
\hline Ptswho did not continue" (n, & \multicolumn{2}{|c|}{$\begin{array}{ll}24 \\
(23)\end{array}$} & \multicolumn{3}{|c|}{15} \\
\hline \multirow{2}{*}{$\begin{array}{l}\text { Ptst that continued, delayed, } \\
\text { or decreased sarilumab dose } \\
(n,(0))\end{array}$} & \multicolumn{2}{|c|}{$\begin{array}{l}81 \\
(77)\end{array}$} & \multicolumn{3}{|c|}{$\begin{array}{l}132 \\
\text { (90) }\end{array}$} \\
\hline & $\begin{array}{l}\text { Continued } \\
\text { without } \\
\text { change } \\
(n=38)\end{array}$ & $\begin{array}{c}\text { Dose delay } \\
(n=43)\end{array}$ & $\begin{array}{l}\text { Continued } \\
\text { without } \\
\text { change } \\
\text { (n=31) }\end{array}$ & $\begin{array}{c}\text { Dose delay } \\
(n=82)\end{array}$ & $\begin{array}{c}\text { Dose } \\
\text { decrease } \\
(n=62)\end{array}$ \\
\hline 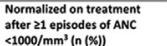 & $\begin{array}{l}25 \\
(66)\end{array}$ & $\begin{array}{l}27 \\
(63)\end{array}$ & $\begin{array}{c}29 \\
(94)\end{array}$ & $\begin{array}{l}66 \\
(80)\end{array}$ & $\begin{array}{l}51 \\
(82)\end{array}$ \\
\hline $\begin{array}{l}\text { Median time to } \\
\text { normalization for patients } \\
\text { with epepisode (days) }\end{array}$ & 9 & 15 & 27 & 17 & 28 \\
\hline 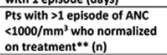 & 6 & 6 & 3 & 33 & 22 \\
\hline $\begin{array}{l}\text { Normalized after treatment } \\
\text { didcontiontion }\end{array}$ & 2 & 9 & 1 & 7 & $\begin{array}{c}5 \\
5\end{array}$ \\
\hline $\begin{array}{l}\text { Discintint notmalize after } 21 \\
\text { episode of ANC }<1000 / \mathrm{mm}^{2}\end{array}$ & $\begin{array}{l}\frac{131}{11^{\circ}} \\
(29)\end{array}$ & (16) & $\begin{array}{l}\text { (3) } \\
\text { (3) }\end{array}$ & $\begin{array}{c}\text { (9) } \\
\text { (11) }\end{array}$ & $\begin{array}{c}\frac{180}{6} \\
(10)\end{array}$ \\
\hline $\begin{array}{l}\text { (n (\%)) } \\
\text { Discontinued treatment due } \\
\text { to abnormal ANC after last } \\
\text { episode (n) }\end{array}$ & 1 & 1 & 1 & 9 & 6 \\
\hline $\begin{array}{l}\text { ANC @ last episode } \\
\left(<2000 / / 1500 /<1000 / \mathrm{mm}^{3} \mid\right.\end{array}$ & $0 / 1 / 0$ & $0 / 1 / 1$ & $1 / 0 / 0$ & $2 / 6 / 1$ & $1 / 4 / 1$ \\
\hline \multicolumn{6}{|c|}{ 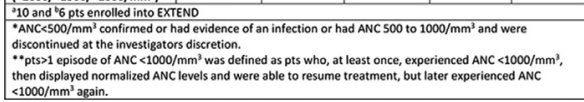 } \\
\hline
\end{tabular}

Methods: In RCTs, patients were required to have baseline neutrophil levels $\geq 2000 / \mathrm{mm}^{3}$. In RCTs and EXTEND, patients who experienced ANC $<500 / \mathrm{mm}^{3}$ (grade 4 [G4] neutropenia) or $\geq 500$ to $<1000 / \mathrm{mm}^{3}$ (grade 3 [G3] neutropenia) and signs of infection were required to permanently discontinue treatment. Patients with G3 neutropenia (no signs of infection) temporarily discontinued treatment (or permanently discontinued at the investigators discretion); patients were retested $\leq 48 \mathrm{hrs}$ after identifying decreased ANC and before the next scheduled dose, and could resume if ANC $\geq 1000 / \mathrm{mm}^{3}$. In RCTs, patients restarted sarilumab at their randomized dose. In OLE, patients restarted sarilumab at $150 \mathrm{mg}$ q2w, as per the protocol, or otherwise were able to restart at $200 \mathrm{mg} \mathrm{q} 2 \mathrm{w}$ at the investigators discretion. In OLE, patients who required a dose decrease to $150 \mathrm{mg}$ q2w sarilumab received the reduced dose for the remainder of the treatment period. ANC normalization was defined as a return to the patient's baseline or within normal ranges. Results: Of the $8-11 \%$ of patients who experienced ANC $<1000 / \mathrm{mm}^{3}$ at any time, $81 / 105$ (RCTs) and 132/147 (OLE) were able to continue or reinitiate sarilumab; the majority of patients who experienced ANC $<1000 / \mathrm{mm}^{3}$ one or more times displayed normalized ANC levels and continued treatment when ANC $\geq 1000 / \mathrm{mm}^{3}$ (25/38 in RCTs; $29 / 31$ in OLE). The majority of patients who dose delayed (27/43 in RCTs; $66 / 82$ in OLE) or dose decreased (51/62, OLE) before ANC normalized resumed treatment.

Conclusions: More than three-quarters of patients who discontinued treatment until ANC normalized were able to reinitiate at their randomized dose (RCT), or at the open-label study dose (200 mg q2w; OLE) or were able to resume at the lowe dose (150 mg q2w; OLE).

Acknowledgements: Study funding and medical writing support (Julie Gray, Adelphi) provided by Sanofi and Regeneron Pharmaceuticals, Inc.

Disclosure of Interest: J. R. Curtis Grant/research support from: Abbvie, Amgen, Bristol-Myers Squibb, Corrona, Janssen, Lilly, Myriad, Pfizer, Roche/ Genentech, UCB, Consultant for: Abbvie, Amgen, Bristol-Myers Squibb, Corrona, Janssen, Lilly, Myriad, Pfizer, Roche/Genentech, UCB, G. St John Shareholde of: Regeneron, Employee of: Regeneron, M. Panucci Shareholder of: Regeneron, Employee of: Boehringer Ingellheim, Regeneron, J. A. Maldonado-Cocco Consultant for: Pfizer, Merck Sharp \& Dohme, Sanofi-Aventis, Novartis, Bristol-Myers Squibb, Roche, Boehringer Ingelheim, Schering-Plough, Abbott, UCB, Eli Lilly Gilead, Speakers bureau: Pfizer, Merck Sharp \& Dohme, Sanofi-Aventis, Novartis, Bristol-Myers Squibb, Roche, Boehringer Ingelheim, Schering-Plough, Abbott UCB, Eli Lilly, Gilead

DOI: 10.1136/annrheumdis-2018-eular.1371

\section{SAT0172 LONG-TERM EFFICACY WITH 5-YEAR-RADIOGRAPHIC RESULTS AND SAFETY OF SARILUMAB IN COMBINATION WITH CSDMARDS IN PATIENTS WITH RHEUMATOID ARTHRITIS}

G. R. Burmester ${ }^{1}$, Y. Lin ${ }^{2}$, G. St John ${ }^{3}$, S. Wang ${ }^{2}$, J. J. Gomez-Reino ${ }^{4}$, J. A. Maldonado-Cocco ${ }^{5}$, J. C. Salazar ${ }^{6}$, D. van der Heijde 7 , M. C. Genovese ${ }^{8}$. ${ }^{1}$ Charité - University Medicine Berlin, Berlin, Germany, ${ }^{2}$ Sanofi Genzyme, Bridgewater, NJ, ${ }^{3}$ Regeneron Pharmaceuticals, Inc, Tarrytown, NY, United States, ${ }^{4}$ IDIS. Complejo Hospitalario Universitario de Santiago, Santiago, Spain, ${ }^{5}$ School of Medicine, Buenos Aires University, Buenos Aires, Argentina, ${ }^{6}$ Clinical Research at Riesgo de Fractura S.A, CAYRE, Bogotá, Colombia, ${ }^{7}$ Leiden University Medical Center, Leiden, Netherlands, ${ }^{8}$ Stanford University Medical Center, Palo Alto, CA, United States

Background: Long-term data are being collected on sarilumab in combination with csDMARDs in patients with RA originally enrolled in six trials (TARGET, NCT01709578; MOBILITY, NCT01061736; NCT01764997; NCT01768572; NCT02057250; NCT01217814) including those who continued into extension trials.

Objectives: To assess efficacy and safety of long-term treatment with sarilumab plus csDMARDs in patients with RA.

Methods: Long-term efficacy and safety data were available in patients enrolled in placebo-controlled trials of sarilumab 150 or $200 \mathrm{mg} \mathrm{sc}$ q2w who continued into the open-label EXTEND trial of sarilumab 200 or $150 \mathrm{mg}$ sc q2w (NCT01146652). Safety data were evaluated in 2887 patients who received $\geq 1$ dose of sarilumab sc in combination with csDMARDs.

Results: Clinical and radiographic efficacy of sarilumab plus csDMARDs was maintained over 5 years' follow-up (table 1; figure 1). Initial treatment with either dose of sarilumab was associated with significantly better radiographic outcome than placebo. Initial treatment with sarilumab $200 \mathrm{mg}$ portended better radiographic outcome than sarilumab $150 \mathrm{mg}$ or placebo. Mean duration of sarilumab treatment in the safety population was 2.6 years ( $\max 6.8)$, representing 7412 cumulative patient-years of exposure. Incidence rate of adverse events of special interest (AESIs; table 2) was generally stable over $>5$ years' treatment, with no signal for increased rate of any AESI (including serious AEs and serious infection) over time. Incidences of injection site reaction, ANC $<1$ Giga/L, \& elevated ALT declined over time. 
Table 1 Clinical response, \% (number of patients assessed)

\begin{tabular}{|c|c|c|c|c|c|c|}
\hline \multirow{2}{*}{$\begin{array}{l}\text { Initial treatment } \\
\text { Week }\end{array}$} & \multicolumn{3}{|c|}{ DAS28-CRP<2.6 (remission) } & \multicolumn{3}{|c|}{$\mathrm{CDAI} \leq 2.8$ (remission) } \\
\hline & \multicolumn{6}{|c|}{ MOBILITY (52 weeks) $\rightarrow$ EXTEND } \\
\hline Week & 148 & 196 & 244 & 148 & 196 & 244 \\
\hline Placebo & $\begin{array}{l}58.6 \\
(249)\end{array}$ & $\begin{array}{l}59.3 \\
(231)\end{array}$ & $\begin{array}{l}63.8 \\
(207)\end{array}$ & $\begin{array}{l}28.1 \\
(249)\end{array}$ & $\begin{array}{l}32.9 \\
(231)\end{array}$ & $\begin{array}{l}36.4 \\
(209)\end{array}$ \\
\hline $\begin{array}{l}\text { Sarilumab } 150 \\
\text { mg }\end{array}$ & $\begin{array}{l}61.9 \\
(239)\end{array}$ & $\begin{array}{l}63.0 \\
(219)\end{array}$ & $\begin{array}{l}63.1 \\
(195)\end{array}$ & $\begin{array}{l}30.5 \\
(239)\end{array}$ & $\begin{array}{l}32.6 \\
(221)\end{array}$ & $\begin{array}{l}34.2 \\
(199)\end{array}$ \\
\hline \multirow[t]{2}{*}{$\begin{array}{l}\text { Sarilumab } 200 \\
\text { mg }\end{array}$} & $\begin{array}{l}67.5 \\
(237)\end{array}$ & $\begin{array}{l}65.3 \\
(225)\end{array}$ & $\begin{array}{l}70.7 \\
(208)\end{array}$ & $\begin{array}{l}36.6 \\
(238)\end{array}$ & $\begin{array}{l}36.7 \\
(226)\end{array}$ & $\begin{array}{l}39.8 \\
(211)\end{array}$ \\
\hline & \multicolumn{6}{|c|}{ TARGET (24 weeks) $\rightarrow$ EXTEND } \\
\hline Week & 48 & 96 & 144 & 48 & 96 & 144 \\
\hline Placebo & $\begin{array}{l}38.1 \\
(139)\end{array}$ & $\begin{array}{l}39.3 \\
(122)\end{array}$ & $\begin{array}{l}41.0 \\
(117)\end{array}$ & $\begin{array}{l}15.9 \\
(138)\end{array}$ & $\begin{array}{l}19.5 \\
(123)\end{array}$ & $\begin{array}{l}17.2 \\
(116)\end{array}$ \\
\hline $\begin{array}{l}\text { Sarilumab } 150 \\
\mathrm{mg}\end{array}$ & $\begin{array}{l}44.9 \\
(136)\end{array}$ & $\begin{array}{l}49.1 \\
(116)\end{array}$ & $\begin{array}{l}53.8 \\
(104)\end{array}$ & $\begin{array}{l}18.1 \\
(138)\end{array}$ & $\begin{array}{l}22.4 \\
(116)\end{array}$ & $\begin{array}{l}23.4 \\
(107)\end{array}$ \\
\hline $\begin{array}{l}\text { Sarilumab } 200 \\
\mathrm{mg}\end{array}$ & $\begin{array}{l}41.4 \\
(140)\end{array}$ & $\begin{array}{l}49.2 \\
(126)\end{array}$ & $\begin{array}{l}53.5 \\
(114)\end{array}$ & $\begin{array}{l}15.7 \\
(140)\end{array}$ & $\begin{array}{l}23.0 \\
(126)\end{array}$ & $\begin{array}{l}24.3 \\
(115)\end{array}$ \\
\hline
\end{tabular}

Table 2 Treatment emergent adverse event rates per 100 patient-years

\begin{tabular}{lll}
\hline & Any AE/SAE & $147 / 9.6$ \\
\hline \multirow{3}{*}{ AEs of special interest } & AE leading to death/discontinuation & $0.4 / 9.1$ \\
& Infections (all/serious/opportunistic/TB) & $54.7 / 3.7 / 0.9 / 0.1$ \\
& Injection site reactions & 24.9 \\
& Hypersensitivity reaction & 5.6 \\
& Malignancy (all/excluding NMSC) & $0.7 / 0.5$ \\
& MACE (primary/narrow) & $0.4 / 0.5$ \\
& Medically adjudicated Gl perforation & 0.1 \\
& Lupus-like syndrome & 0.1 \\
\hline
\end{tabular}

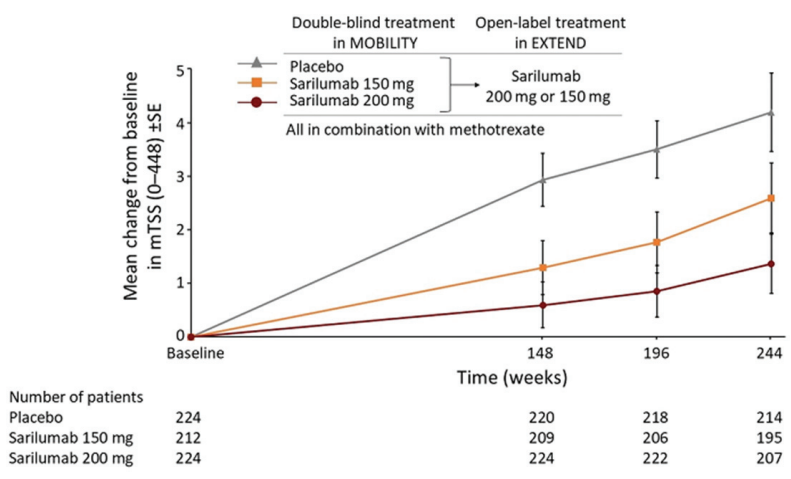

Figure 1 Change in mTSS in patients who completed 52-week double-blind MOBILITY study and subsequently entered open-label EXTEND studyConclusions: Clinical efficacy and inhibition of progression of structural damage with sarilumab plus csDMARDs was sustained up to 5 years of follow-up in patients with diverse prior pharmacologic therapies. The safety profile of sarilumab plus csDMARDs remained stable over $>5$ years' treatment.

Acknowledgements: Study sponsored by Sanofi and Regeneron Pharmaceuticals, Inc, who funded medical writing support by Matt Lewis, Adelphi Group

Disclosure of Interest: G. R. Burmester Grant/research support from: AbbVie, Pfizer, UCB, Roche, Consultant for: AbbVie, Lilly, Merck Sharpe \& Dohme, Pfizer, Sanofi, Roche, UCB, Speakers bureau: AbbVie, Lilly, Merck Sharpe \& Dohme, Pfizer, Sanofi, Roche, UCB, Y. Lin Shareholder of: Sanofi Genzyme, Employee of: Sanofi Genzyme, G. St John Shareholder of: Regeneron, Employee of: Regeneron, S. Wang Employee of: Sanofi, J. J. Gomez-Reino Grant/research support from: Roche, Merck Sharpe \& Dohme, Consultant for: Biogen, Gilead, Lilly, Merck Sharpe \& Dohme, Pfizer, Speakers bureau: Bristol-Myers Squibb, Janssen and Janssen, Merck Sharpe \& Dohme, Pfizer, Roche, Sandoz, J. A. MaldonadoCocco Consultant for: Pfizer, Merck Sharpe \& Dohme, Sanofi-Aventis, Novartis, Bristol-Myers Squibb, Roche, Boehringer Ingelheim, Schering-Plough, Abbott, UCB, Eli Lilly, Gilead, Speakers bureau: Pfizer, Merck Sharpe \& Dohme, SanofiAventis, Novartis, Bristol-Myers Squibb, Roche, Boehringer Ingelheim, ScheringPlough, Abbott, UCB, Eli Lilly, Gilead, J. C. Salazar Grant/research support from: Pfizer, Abbvie, Consultant for: Glaxo, Pfizer, Abbvie, UCB, Janssen, Speakers bureau: Roche, Abbvie, Janssen, D. van der Heijde Shareholder of: Imaging Rheumatology bv., Consultant for: AbbVie, Amgen, Astellas, AstraZeneca, Bristol-Myers Squibb, Boehringer Ingelheim, Celgene, Daiichi, Eli-Lilly, Galapagos, Gilead, GlaxoSmithKline, Janssen, Merck, Novartis, Pfizer, Regeneron, Roche, Sanofi, Takeda, UCB, M. C. Genovese Grant/research support from: Sanofi/
Genzyme, Genentech/Roche, RPharm, Consultant for: Sanofi/Genzyme, Genentech/Roche, RPharm

DOI: 10.1136/annrheumdis-2018-eular.1373

\section{SAT0173 EFFECTS OF DENOSUMAB, A SUBCUTANEOUS RANKL INHIBITOR, ON THE PROGRESSION OF STRUCTURAL DAMAGE IN JAPANESE PATIENTS WITH RHEUMATOID ARTHRITIS TREATED WITH CSDMARDS: RESULT FROM THE LONG-TERM TREATMENT OF PHASE 3, DESIRABLE STUDY}

T. Takeuchi ${ }^{1}$, Y. Tanaka ${ }^{2}$, S. Soen ${ }^{3}$, H. Yamanaka ${ }^{4}$, T. Yoneda $^{5}$, S. Tanaka ${ }^{6}$, T. Nitta ${ }^{7}$, N. Okubo ${ }^{7}$, H. Genant ${ }^{8}$, D. van der Heijde ${ }^{9} .{ }^{1}$ Keio University School of Medicine, Tokyo, ${ }^{2}$ University of Occupational and Environmental Health, Kitakyushu, ${ }^{3}$ Kindai University Nara Hospital, Ikoma, ${ }^{4}$ Institute of Rheumatology Tokyo Women's Medical University, Tokyo, ${ }^{5}$ Osaka University Graduate School of Dentistry, Osaka, ${ }^{6}$ The University of Tokyo, ${ }^{7}$ Daiichi Sankyo, Tokyo, Japan,

${ }^{8}$ University of California, San Francisco, United States, ${ }^{9}$ Leiden University Medical Center, Leiden, Netherlands

Background: Denosumab is a fully human monoclonal antibody ( $\left(g G_{2}\right.$ subclass) that inhibits bone resorption by inhibiting RANKL, a key mediator of osteoclast for mation, function, and survival. The effect of denosumab on the progression of joint damage in patients with RA on csDMARDs background treatment from the first 12 months (double-blind, placebo-controlled) of the Phase 3 DESIRABLE study has previously been reported. ${ }^{1}$

Objectives: To evaluate the safety and efficacy of long-term treatment with denosumab $60 \mathrm{mg}$ every 6 months (Q6M) or every 3 months (Q3M) with RA patients in long term treatment phase of the DESIRABLE study.

Methods: Upon completion of the 12-month, double-blind phase, all patients were to receive denosumab $60 \mathrm{mg} / \mathrm{Q} 6 \mathrm{M}$ or $60 \mathrm{mg} / \mathrm{Q} 3 \mathrm{M}$ and calcium and vitamin $\mathrm{D}$ daily during the 36 -month, open-label extension phase. Patients were randomized in a 1:1:2:2 ratio to receive one of four treatments (figure 1). In this analysis, the continuous administration group received 36 months of denosumab treatment, and the cross-over group received 24 months of denosumab treatment (12 month of placebo in DB phase and 24 months of denosumab treatment phase). The radiographic evaluation was the change from baseline to 12,24 and 36 months in the van der Heijde modified total Sharp score (mTSS). Radiographs of hands and feet at baseline, 12, 24 and 36 months were scored with blinded time order by 2 readers independently. Average score of the 2 readers is used for the analysis Missing scores were imputed using linear extrapolation/interpolation.

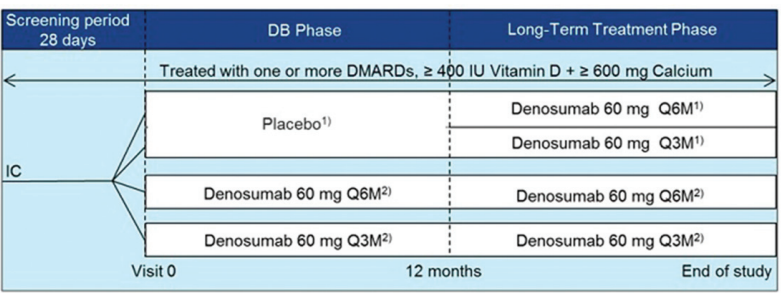

1) : Cross-over group, 2) : Continuous administration group

Figure 1 Study design

\begin{tabular}{|c|c|c|c|c|c|}
\hline \multirow[b]{2}{*}{ Characteristic } & \multirow[b]{2}{*}{ Visit } & \multicolumn{2}{|c|}{ Cross-over group } & \multicolumn{2}{|c|}{ Continuous administration group } \\
\hline & & $\begin{array}{l}\text { Placebol } \\
\text { denosumab } \\
60 \mathrm{mg} 06 \mathrm{M} \\
\mathrm{N}=105\end{array}$ & $\begin{array}{l}\text { Placebol } \\
\text { denosumab } \\
60 \mathrm{mg} Q \mathrm{QMM} \\
\mathrm{N}=101\end{array}$ & $\begin{array}{c}\text { Denosumab } \\
\text { Bomg } \triangle 6 \mathrm{M} \\
\mathrm{N}=191\end{array}$ & $\begin{array}{l}\text { Denosumab } \\
\text { 60mg } Q 3 \mathrm{M}\end{array}$ \\
\hline \multirow{3}{*}{ mTSS } & 12 months & $1.29 \pm 2.86$ & $1.60 \pm 3.62$ & $1.25 \pm 4.16$ & $0.98 \pm 3.01$ \\
\hline & 24 months & $2.33 \pm 4.73$ & $2.05 \pm 4.35$ & $2.12 \pm 6.10$ & $1.42 \pm 4.02$ \\
\hline & 36 months & $2.93 \pm 6.56$ & $2.49 \pm 4.70$ & $2.26 \pm 6.66$ & $1.71 \pm 4.59$ \\
\hline \multirow{3}{*}{ ES } & 12 months & $0.79 \pm 1.76$ & $0.97 \pm 2.48$ & $0.70 \pm 2.39$ & $0.27 \pm 0.98$ \\
\hline & 24 months & $1.23 \pm 2.36$ & $1.01 \pm 2.48$ & $1.09 \pm 3.55$ & $0.35 \pm 1.35$ \\
\hline & 36 months & $1.54 \pm 3.39$ & $1.18 \pm 2.56$ & $0.96 \pm 3.36$ & $0.40 \pm 1.31$ \\
\hline \multirow{3}{*}{ JSN score } & 12 months & $0.51 \pm 1.44$ & $0.63 \pm 1.75$ & $0.55 \pm 2.13$ & $0.71 \pm 2.42$ \\
\hline & 24 months & $1.10 \pm 2.87$ & $1.04 \pm 2.27$ & $1.03 \pm 3.13$ & $1.07 \pm 3.20$ \\
\hline & 36 months & $1.39 \pm 3.83$ & $1.31 \pm 2.57$ & $1.30 \pm 4.04$ & $1.31 \pm 3.67$ \\
\hline
\end{tabular}

Table 1 Change from baseline in mTSS, ES and JSN score in DB and long-term treatment phaseData presented are mean \pm SD

Results: 667 (placebo/Q6M (P/Q6M), n=113; placebo/Q3M (P/Q3M), $n=110$; $\mathrm{Q} 6 \mathrm{M}, \mathrm{n}=222 ; \mathrm{Q} 3 \mathrm{M}, \mathrm{n}=222)$ received at least one dose of study drug, and $607(\mathrm{P} /$ Q6M, $n=105 ; P / Q 3 M, n=103 ; \mathrm{Q} 6 \mathrm{M}, \mathrm{n}=199 ; \mathrm{Q} 3 \mathrm{M}, \mathrm{n}=200$ ) completed the DB period and entered the long-term extension. In both continuous administration and 